\title{
UMA (OUTRA) PEQUENA HISTÓRIA DA FOTOGRAFIA: SYLVIO DA CUNHA ${ }^{1}$
}

\author{
(Another) little history of photography: \\ Sylvio da Cunha
}

Raul Antelo*

\begin{abstract}
RESUMO
A fotografia mostrou a existência de um inconsciente ótico, assim como descobrimos o inconsciente por intermédio da psicanálise. Permitiu-nos conhecer aspectos materiais dos mundos imagéticos, que lidam com as minúcias, prenhes de significação, embora sequiosas por um lugar recôndito nos sonhos acordados, mas que, ampliadas e exibidas, fazem a diferença entre técnica e magia. Estas ideias, formuladas por Benjamin em seu famoso ensaio de 1931 sobre a fotografia, são compartilhadas por um relativamente desconhecido artista brasileiro, Sylvio da Cunha.

Palavras-chave: inconsciente ótico; fotografia; surrealismo.
\end{abstract}

\begin{abstract}
Photography revealed the existence of optical unconscious, just as we discovered the unconscious through psychoanalysis. Photography let we know material aspects of image worlds, which dwell in the smallest things - meaningful yet looking for a hiding place in waking dreams, but which, enlarged and exhibited, make the difference between technology and magic. These ideas formulated by Benjamin in his famous 1931 essay on photography are shared with a rather unknown Brazilian artist, Sylvio da Cunha.
\end{abstract}

Keywords: optical unconscious; photography; surrealism.

"Universidade Federal de Santa Catarina.

1 Este texto foi originalmente apresentado num colóquio PROCAD-Poesia, em Florianópolis, dezembro de 2013. 
Um arquivista, que nada tem de dialético, enfatiza a tautológica estupidez (Clément Rosset) da fotografia, cujos efeitos políticos de massa, enquanto sonho acordado (dreamworld, segundo Buck-Morss), são inegáveis. Define assim o passado como aquilo que nos atinge e a história, como algo diferente dos documentos acumulados pelos arquivos: a história é montagem de temporalidades diversas que, mais do que se lerem conforme o ça $a$ été barthesiano, obedecem à ilusão do já-vivido. A fotografia elabora, portanto, um novo campo de reflexão para a estética, ler o que nunca foi escrito, uma vez que algo contingente, como uma mancha ou uma sombra, torna-se uma reflexão sobre o tempo. A fotografia, como prótese perspectivista, abre assim uma nova dimensão da arte, colaborando para o incipiente domínio do museu, mesmo que imaginário, à maneira de Malraux, porque todo museu, no fundo, não deixa de ser um museu de fotografia; mas, pelo contrário, na suspensão da percepção, que Bataille ou Blanchot já apontaram no museu, residiria o espectro de uma destinação, o museu como câmara de reclusão e confinamento da imagem.

Engana-se quem pense que estou falando de Walter Benjamin'; falo porém de Sylvio da Cunha (1907-1995), bem menos conhecido do que o crítico alemão. $\mathrm{O}$ anatoliano Tristão da $\mathrm{Cunha}^{3}$, durante longos anos colaborador do Mercure de France, inclui em seu livro Coisas do tempo (1922), em clara sintonia, aliás, com Rémy de Gourmont ou Ernest Renan, um diálogo dos mortos que é, a rigor, uma conversa entre duas sombras. Um quarto de século mais tarde, seu primo, Sylvio da Cunha, reencenaria o diálogo das sombras para elaborar a primeira teoria da fotografia no Brasil.

2 «Un appareil comme la photographie qui brise l'échange des regards puisqu'il ne répond pas au regard de celui qui est photographié, cet appareil n'est-il pas en son fond émancipateur: ne générant que des archives objectives, non auratiques? Conclusion: Benjamin a produit en creux le modèle de l'appareil 'passage' en utilisant la problématique freudienne de l'appareil psychique. Ce faisant, il donne une autre assiette à la vérité: non plus la rationalisation et la certitude de l'ego cogito cartésien qui s'opposaient aux savoirs incapables de donner raison d'eux-mêmes (les illusions des sens, le pouvoir des histoires, etc.), mais l'écriture proustienne qui perlabore un savoir à partir des traces mnésiques inconscientes. Le passage est un véritable appareil configurant à nouveaux frais l'événement et non un simple dispositif urbain parce que modifiant le milieu de la perception, il a rendu possible le renouvellement d'un genre littéraire: la poésie lyrique ». DÉOTTE, Jean-Louis. La ville appareillée: Arendt, W. Benjamin et Baudelaire. Revue Appareil, 2008. URL: < http://revues.mshparisnord.org/appareil/index.php?id=449>. Do mesmo autor, L'Homme de verre. Esthétiques benjaminiennes. Paris, 1998; La época de los aparatos.Trad. A. Oviedo. Buenos Aires: Adriana Hidalgo, 2013; ¿Qué es un aparato estético? Benjamin, Lyotard, Rancière. Santiago do Chile: Metales Pesados, 2012.

3 Ver Autores e livros, v. III, n. 18. A Manhã, Rio de Janeiro, 13 dez. 1942. 
Ao anunciar, com efeito, o início da coluna "Os pássaros do retratista", o jornal Letras e Artes assim apresentava o novo colaborador:

É autor de dois livros publicados fora do comércio, Constança e Memória da Paisagem do Anjo. Em 1943, Sylvio da Cunha se tornou repentinamente um autêntico aficionado da fotografia. Seus trabalhos foram dos mais relevantes, nesse período. Sempre preocupado em estudar a parte da física que trata dos fenômenos luminosos, adquiriu um telescópio e mais tarde um microscópio, tendo com este feito fotografias de algas e preparações anatômicas de zoologia e botânica. Em 1941, começou a acreditar nas possibilidades da fotografia como arte, fazendo as primeiras composições e procurando conhecer a obra de fotógrafos contemporâneos e antigos. Fez em seguida uma série de foto-micrografias para o Instituto Nacional de Cinema Educativo. Expôs recentemente em Quitandinha e aparecerá brevemente numa exibição no Photography Center do Museu de Arte Moderna de Nova York ${ }^{4}$.

Antes, porém, em 4 de junho de 1947, Sylvio da Cunha começa a mostrar suas próprias fotos no Instituto dos Arquitetos do Brasil, na Praça Floriano, no prédio da Livraria Victor ${ }^{5}$, exposição a cuja abertura ele próprio não compareceu; mas, a essas alturas, Sylvio já era conhecido: estreara sua coluna no Letras e Artes havia dois meses. Foi no domingo de Semana Santa e o suplemento se abria precisamente com uma frase do introito da missa pascoal, "Ressurrexi, et adhuc tecum sum. Alleluia!, alleluia!", que descortinava, em toda a extensão da capa, a imagem da Ressurreição do Mestre do Retábulo de Santos-o-Velho, conservada no Museu Nacional de Arte Antiga de Lisboa, em cujos painéis, segundo Murilo Mendes, fecha-se

4 Letras e Artes, Rio de Janeiro, n. 36, 30 mar. 1947. Na gestão de Alfred Barr Jr., empossado naquele ano, Edward Steichen, que pertencera ao círculo de Stieglitz, assume o Departamento de Fotografia do MoMA e planeja uma grande exposição sobre fotografia como arte para 1948. É possível, porém, que alguma fotografia de Sylvio da Cunha tenha sido incluída em outra exposição no MoMA, a do projeto de Cidade dos Motores, da autoria de Paul Lester Wiener e José Luis Sert, que abriu no museu em junho de 1947. Sobre o autor, ver VÁRIOS AUTORES. Sílvio Leitão da Cunha: um renascentista contemporâneo. Rio de Janeiro: Fundação Casa de Rui Barbosa, 1987. Agradeço a obtenção dos materiais da Casa de Rui Barbosa a Marcelo Santos. 2,8 jun. 47.

5 Exposição de arte fotográfica de Sylvio da Cunha. Letras e Artes, Rio de Janeiro, n 44, p. 
o ciclo medieval das miniaturas e começa o da monumentalidade moderna ${ }^{6}$. O ícone saía, finalmente, das sombras, mas nem por isso o cinema, diria Godard, tal como o cristianismo, nasce de uma verdade histórica ${ }^{7}$. Como o mesmo Sylvio da Cunha admitia, logo no incipit da primeira crônica, numa evidente captatio benevolentiae, o título com que batizara os textos não era dele, mas provinha de uma frase de seu amigo Carlos Drummond de Andrade, referindo-se à "câmara escura onde adormecem os pássaros do retratista", expressão recolhida pelo autor como uma passagem de "escadas profundas para o sonho". Cabe relembrar aqui o intenso diálogo, que se firma entre 1943 e 1945, entre Sylvio e Drummond. Logo em uma das primeiras cartas, em fevereiro de 1945, o fotógrafo confidencia ao amigo ter achado uma imagem da Vila do Carmo, 1880, com uma moça de tranças, que Sylvio logo identifica com a poesia (“Ó Carlos, ó Minas Gerais") para, a seguir, ensaiar uma definição da poesia:

Esta é o próprio pensamento jorrando como água viva [...] É a força da síntese poética que traz do caos (no sentido mais metafísico) as relações ainda não pressentidas e as faz do domínio geral do conhecimento até que passem à categoria analítica como sinais de espécie e de ordem; é ainda essa força que se renova periodicamente, quando as associações se esgotam e a expressão se torna impotente para cumprir o seu fim mais alto, que é a criação de aspectos novos do espírito: os poetas não são somente os criadores da poesia, mas da própria linguagem e todas as formas artísticas, e, unicamente por uma questão de situação na História, também têm sido denominados de legisla-

6 Murilo foi amigo de Sylvio e seus textos sobre as fotomontagens de Jorge de Lima dialogam com sua teoria. Cf. MENDES, Murilo. Poesia e fotografia. Correio da Manhã, Rio de Janeiro, 20 abr. 1963.

7 "Há evidências que não podem ser provadas, mas que nunca perdem o seu caráter de evidências. No crescimento das plantas e dos animais, na inteligência do homem e no movimento dos astros adivinhamos um poder previdente, matemático e organizador. Percebemos vagamente alguns, com mais certeza outros, tal como o herói de uma das histórias de assombramentos de Edgar Poe, que não estamos sós, que fora de nós, sem nome, silencioso, imponderável, mas irresistível, há alguém que trabalha, que constrói, que às vezes faz pequenos milagres, desses que passam despercebidos da maioria, numa pequena semente jogada na terra ou numa simples flor do vale. A Religião, que é muito mais velha que nós, mais velha que as ciências e as filosofias, conhece esse personagem misterioso e sabe bem o seu nome. Se nos dizem que é Deus, não ficamos ainda satisfeitos; pedimos uma palavra que salve a finalidade humana do mundo, a nossa angústia, vital de perfeição e justiça, de eternidade e infinidade, estamos esmagados entre as forças formidáveis do cosmos e o que queremos, em suma, é um Deus de amor que nos salve. Agora sabemos o seu verdadeiro nome. É o Salvador, Jesus. Uma luz brilha nas trevas”. CUNHA, Sylvio da. Nem só de foto... Letras e Artes, Rio de Janeiro, n. 72, p. 6, 11 jan. 1948. 
dores ou profetas, Job ou Solon, porque o poeta não só percebe uma extensão maior do presente que o comum dos mortais, como pela imaginação vê o passado e o futuro. Pela imaginação habita a eternidade e o infinito e participa da divindade. ${ }^{8}$

Não custa, portanto, ver a sombra de Sylvio no esboço de teoria da imagem que Drummond escreve em $1949^{9}$ e mesmo em seus poemas da época, como "Consideração do poema", "Procura da poesia", "Resíduo" ou "Nosso tempo", ainda mais se pensamos que Sylvio começa sua carreira frequentando o círculo de um mallarmeano como Alfonso Reyes, sobre quem escreve artigo em O Jornal, em 1935. Seja como for, assim definida a poesia, diríamos que os "pássaros do retratista" são determinados por uma poética dos fenômenos, mas vêm carregados, por exemplo, dos mistérios do tempo, das alegrias matinais de antigamente, dos risos e dos aniversários da criança que cresceu e foi depois envelhecendo nos álbuns de veludo ${ }^{10}$, ou seja, são, nem mais, nem menos, fotografias da memória da mais pura estirpe benjaminiana. A origem é montagem e todo erudito alimenta-se de um fantástico de biblioteca.

Deixando de lado outros modos de existência, mineral, vegetal, animal ou estelar, uma especulação diferente me submerge sem esforço nem tormento num estado virtual de serenidade e beatitude. Em superfície imensa, lisa, percebo bem que ilimitada, azul e branca, dotado de consciência, visão, sentidos, memória, a planície ou lago é quieto e profundo, sou apenas uma ruga no plano que nada toca, sou uma simplíssima, rudimentar ruga somente. Nesse estado ideal de ruga, o poder de contemplação se distende sem obstáculo lá fora, e, nada encontrando, volta-se para dentro de si mesmo. Uma realidade maior se desenrola então na memória. As fotografias da memória, imóveis ou elásticas, caprichosas ou fiéis, têm o seu lugar certo no quadrante misterioso e feito de camadas sucessivas do espírito.

8 CUNHA, Sylvio da. Carta a Carlos Drummond de Andrade (Petrópolis 4, fev. 1945). Depositada no Museu de Literatura Brasileira, Fundação Casa de Rui Barbosa.

9 M. P. (pseudônimo de Carlos Drummond de Andrade). Retratos do artista quando menino. Jornal de Letras. Rio de Janeiro, nov. 1949. O título arremeda o texto de Joyce que fora oportunamente resenhado por Drummond na Revista Acadêmica (Rio de Janeiro, a. 12, n. 68, jul. 1947).

10 CUNHA, Sylvio da. Os pássaros do retratista. Letras e Artes, Rio de Janeiro, n. 37, 6 abr. 1947 , p. 10. 
Não haveria máquina, por mais inteligente que fosse, capaz de colhê-las; elas são feitas de poesia e de intuição impalpáveis, de segredo apenas pressentido, de música incerta e subterrânea ${ }^{11}$.

\begin{abstract}
Essas imagens do pensamento, em tudo congeniais com as de Benjamin $^{12}$, Da Cunha chamava-as caprichos do olhar e delas nos deu alguns exemplos. O primeiro deles, que capta a vida das formas de Henri Focillon ou as protoformas da arte, na linha ensaiada por Karl Blossfeldt, misturando-as com vestígios de Bandeira ou mesmo Mário de Andrade, chama-se "Bailado do último cactus", e diz:
\end{abstract}

$\mathrm{Na}$ terra odorante há rosas enormes que se confundem com as rosas do poente no céu. A geometria vegetal das folhas

11 Transcrevo algumas dessas imagens da memória, autênticas dobras da imaginação. "O menino", por exemplo, diz "Domingo solar. A rua deserta, sem um arranhão no silêncio vegetal e de pedra. O olhar entra por acaso com um raio de sol por uma janela qualquer. Dentro há um espelho. Na sua superfície pura reflete-se o chão, o tapete, um trenzinho de brinquedo. O menino não se vê. Só meus passos soavam na calçada, pensando no menino invisível que o espelho escondeu para sempre". "O quarto de brinquedos": "Aqui as lembranças são uma estrela fugitiva, entre as nuvens do ouvido. Um pequeno mundo em que o olhar tem o comprimento do gosto, mas em que os limites se ampliavam ao infinito, nas paredes cobertas de gravuras de velhas Illustrations. Aquário sombrio e ardente (ó Rimbaud!) de visões que nunca mais me abandonaram". O fragmento de "Noite antiga" diz: "As patas dos cavalos batiam surdamente na rua. Ouvíamos ranger a vitória que se dobrava macia nas pontes vermelhas. A luz fraca das lanternas já era um começo de sonho. Eu mostrava ao meu pai a casa com cara de gente e ele ria. Tinha mesmo cara de gente a casinha que os grilos faziam boiar no sossego enorme do morro". A cena "Infância" diz: "A minha infância: - Lanterna de vidro de cores / Acesa na noite". E "A casa do meu avô", "Ficava numa pequena elevação da rua, a casa do meu avô. O ar era de vez em quando afinado pelo apito e pela sineta do trem, ou pelo grito das galinhas de Angola. Da calçada eu via o meu avô sentado, olhando para a paz provinciana. Abria-se a porta sobre o vestíbulo que era um banho de ordem e calma. O criado sumia na ponta dos pés e eu aspirando a leve atmosfera perfumada de linho, de madeira, de flores secas, de coisas velhas, galgando as escadas, já ia transpondo as fronteiras de um mundo diferente que flutuava no olhar contemplativo do meu avô, nas suas pupilas azuis, nas suas mãos lentas e graves". Em "A torneirinha", lemos: "A nossa civilização elétrica dividiu o tempo em frações cada vez menores. Avos de segundo são de uso corrente em nossa era. Mas antes das duas guerras que marcam a nossa trágica época, os relógios não andavam tanto. As horas tinham um perfume de eternidade. O tio Otávio, logo ao entrar em casa pela porta do lado, lavava as mãos. A piazinha, alta e estreita, era bonita, de louça com arabescos azuis. O sabonete, fresco e cheirosíssimo. Mas o mais notável era a torneira, muito junto da pia, com a particularidade, num tempo em que ainda não se conhecia falta d'água, de destilar um tênue fio de líquido. A operação de ensaboar as mãos e depois tirar a espuma tornava-se assim demorada e laboriosa. Estou certo que o tio Otávio, homem de ação e movimento, mas de hábitos inamovíveis, nunca quis mandar que desapertassem a bucha da torneira, porque no fundo apreciava imensamente aquela pausa deliciosa, em que repousava o seu espírito entre os dois escritórios, o da cidade e o de casa". CUNHA, Sylvio da. Fotografias da memória. Letras e Artes, Rio de Janeiro, n. 86, p. 11, 25 maio 1948.

12 USLENGHI, Alejandro (Ed.). Walter Benjamin. Culturas de la imagen. Buenos Aires: Eterna Cadencia, 2010. 
se multiplica em desenhos inesgotáveis que a visão percorre magnetizada, e o mundo dos insetos é uma superalucinação inesperada e deliciosa. Abre-se mais uma urna, fechada desde a eternidade, derramando o perfume da euforia paradisíaca. A alegria subterrânea se transforma, conquista o ar em danças e cantos em festa. Depois da noite infindável, os sonhos vêm descendo dos silêncios estelares e são tocados invencivelmente. Numa ruga do oceano cintilam peixes comemorativos, narcisismos e amores do mar, da água e do sol. Mas sob o colóquio milenário do vento e da montanha inacessível, o Basilisco fixa o deserto inviolável, criado pelo seu olhar soberano e aniquilador do horrível do último cactus ${ }^{13}$.

13 O segundo capricho é uma "Gravura ao gosto antigo". Diz: "Isto é do tempo em que havia tinteiros. Severos e senhoriais de bronze, de marfim, de ônix. A tinta negra lançava reflexos estranhos do oscilar da mesa sob a lâmpada incerta. As sombras engrandecidas dos mais vulgares objetos dilatavam a imaginação até as fronteiras do absurdo e dos azuis imensos da infância, do amor e da morte. Quando um raio de luz tocava o fluido, o líquido tenebroso parecia guardar um mistério inquietante, abafado no impenetrável negror da tinta. Numa dessas noites em que a penumbra jogava com inexplicáveis, arabescos em torno, uma veludosa visão de pluma esboçou um gesto de contar segredos imemoriais. A pena rangia arranhando sem descanso o papel que se cobria de espantos, belo como um palimpsesto. Inesperadamente, vi tremer no fundo do tinteiro de outrora a última gota. Duas, três vezes a pena ávida buscava-a, e ela fugia, esquiva. Ansioso, inclinei o bronze maciço para que a pena sorvesse o diamante sombrio, inquieto, irreparável e eis que a gota diabólica palpita e tomba sobre o campo sem sombra do papel, inumerável de votos suspensos, mundos incriados. E oh! pesadelo! A mancha caprichosa e incerta sob a pesada atmosfera de fumaça e desvario do quarto estendeu-se em limites incríveis e delineou a figura inopinadamente animada de uma zombaria infernal, singular e logo sem dúvida na sua fixidez, insuportável!". O terceiro capricho, porém, é contemporâneo, "Desenho animado", e conta, em chave surrealista, que "houve como o silêncio que sucede ao esmagamento súbito de um piano. Então do personagem central um olho saltou a vinte centímetros da testa, a testa encurvou-se ameaçadoramente sobre o nariz que entrou a espadanar como um peixe fora d'água, as orelhas se esticaram em pontas felinas e um dente começou, da boca enorme e negra, a crescer e a perseguir a vítima ímpede que fugia espavorida. O som detonante de uma palavra destruidora parou os relógios, derrubou os livros, as estatuetas, os jarros de flores, quebrou as vidraças e as lâmpadas do bairro e pôs imediatamente de prontidão temerosa, perplexa, o exército, a marinha, as estações do corpo de bombeiros e a polícia. Não foi em vão, pois logo em seguida os olhos do personagem central começaram a despedir chispas altamente eletrizadas que incendiaram as cortinas, os tapetes, os móveis, fazendo arder o edifício de quatorze andares, as docas, as usinas, os ministérios, produzindo instantaneamente o pânico internacional e precipitando os aeroanfíbios-tanques numa voragem macabra de massacre a milhões de trilhões de rotações por segundo". Por último, da Cunha transcreve o quarto capricho, em forma de crônica, "O caso do copo d'água": "Nada mais natural do que às duas horas da madrugada encher um copo d'água e antes de o beber deixá-lo alguns instantes sobre o mármore do velho buffet obsoleto. Até aí nada de extraordinário. Mas, supondo que a luz não se apague, que a nossa vista seja bastante clara, a mente lúcida e o olhar depois de descrever uma parábola inconsciente, da janela ao relógio de parede e do relógio de parede novamente ao buffet obsoleto, procure o copo d'água e não o encontre? É certo, ele aí não está. Ninguém entrou na sala, eu não sou, nem nunca tive a personalidade de mágico, que poderia assim absorver a minha atual e enganá-la. Tão pouco o vaso se acha no solo, partido, a água derramada. Tenho certeza que o coloquei aqui, há meio minuto. Minha memória está intacta. Poderia reconstituir todos os movimentos até o instante em que enchi o copo e o coloquei sobre o mármore puído, profusamente veiado mas inteiramente despido, sem objeto algum sobre a sua superfície. Olho o mármore. Disse profusamente veiado. É certo. 
Mais do que uma teoria da fotografia, Sylvio da Cunha ensaiava, em sua coluna, uma antropologia do sensível, sob o ponto de vista da imagem, tal como os pioneiros Alfred Stieglitz ou Marius de Zayas, nas páginas de Camera Work, mas seu referencial, à diferença dos precursores, era basicamente poético e europeu, por isso, entrando em matéria, o autor logo evoca os primórdios dessa linguagem, não sem antes lhe apontar as sobrevivências do mundo mágico ancestral:

\begin{abstract}
No século dos prodígios, a nova e estranha figura do Fotógrafo apareceu armada das insígnias da feitiçaria. Engrimanços, alambiques, caixinhas de segredo não lhe faltavam. Uma gazeta de 1839 assim se alarma: "É sacrilégio querer gravar as imagens das criações de Deus com máquina humana de infernal invenção". O resultado da sua alquimia inquietadora, das suas manipulações singulares, dos seus sortilégios, estabelecia logo a atmosfera da fantasia e do sobrenatural. Inesperadamente nos pequenos espelhos de metal surgiam visões terríveis, espectros de fixidez alucinantes, fantasmas do outro mundo com aspecto de uma glacial realidade. Como não poderia deixar de ser, o
\end{abstract}

Caprichosamente se misturam o preto, o cinza, o branco, nas suas manchas variadas, que atestam como terão sido revolvidas as luvas agora cristalizadas nesta silenciosa, fria e imóvel, matéria marmórea". Sylvio da Cunha pondera então que os caprichos se vinculam a certas fantasias óticas, tais como "ver a sombra da roupa desenhar um perfil humano ou de animal no chão; uma bolha no sabonete e um pouco de espuma formam um olho e um nariz, tudo faz uma expressão de espanto; alguma folhagem, ao cair da tarde de sol, projetava ontem no muro um coelhinho, a que a brisa dava vida; vi as dobras de um lenço formarem uma cara de gente e um papel de embrulho amarrotado num canto compor uma face austera, episcopal. São geralmente figuras nirvânicas, expressando uma grande concentração de indiferença e alheamento. Caras de mortos. Espesso de arabescos como uma floresta, este mármore. É sem trabalho que o meu olhar fixo perplexo, com o desaparecimento do copo d'água, vê nas sinuosas veias surgirem dois cavalheiros da Inquisição, ou da Ku-Klux-Klan. Em seguida vem um cachorro sem mandíbula inferior junto de um velho com a boca desmesuradamente aberta. É o olhar que desenha estes monstros ou eles existem, no seu estado de pedra? Onde está a realidade? O olhar vai girando e vê o cavalo com cara de passarinho, cuja perna da frente é um martelo e cujo corpo é um estandarte esfarrapado. O rato aí está, com cabeça de barata. Um homúnculo se bifurca em pássaro e a sua perna o precede agressiva, em atitude de marcha prussiana. Um boi tem bigodes e um olho no meio da testa. Um cachorrinho devora uma flor com a pata dianteira. Um ancião de cavanhaque, cuja cabeleira forma a efígie de Lamartine. De costas, uns ombros, uma cartolinha, que poderiam ser de Carlitos. Três figuras, sendo duas encapotadas e um homem com corpo de peixe. Cara de homem vociferando e orelha de gato. Mulher com chapéu de astrólogo cujo corpo forma um focinho de cão. Figuras de Guernica, de Breughel e Bosch, de Salvador Dali. Caras repuxadas ora nos olhos, ora na boca, nos lábios, com um só olho, ou sem boca ou sem nariz, caras cortadas ou meio dissolvidas. Mistérios do mármore. Boca enorme engolindo uma árvore. Aos pés da árvore vejo enfim o copo d'água. Caprichos do olhar". CUNHA, Sylvio da. Caprichos do olhar, Letras e Artes, Rio de Janeiro, n. 58, p. 8, 14 set. 1947. Trata-se do mesmo fenômeno que Didi-Huberman analisará, a partir de Goya, como estratégia para montar um atlas warburguiano da memória. 
narcisismo dos primeiros fascinados tornou-se indiferente à natureza. A paisagem, demasiado semelhante a si mesma depois de aprisionada, olhava-se num embaraço de detalhes de uma familiaridade e constância que tornavam inútil a sua reprodução. Baudelaire, que conheceu a fotografia apenas na sua fase primitiva, de um realismo cuja única função era assombrar olhos ingênuos, não previu as futuras aparições, não de pasmos, mas agudíssima liberdade criadora, em que o elemento composição pôde ser isolado em despida pureza. Não a perturba nem sequer a beleza da matéria, que é triste, como o são simples sombras. Mas a nova Cendrillon que vem das fuligens da cozinha traz também o calor do sol consigo. Na pobreza do papel branco e negro, não há gostosos traços de pincel nem crayon, mas a sua posição, isolada em seus domínios absolutos, como reina poderosamente!

Na sua inconstância e nas suas vicissitudes procuraremos também o seu lirismo e a sua poesia. Há uma poesia de sugestão nos velhos daguerreótipos abandonados em que a nossa obstinação contemplativa sente um raio de aurora reviver. Mas há também uma poesia real em certos retratos onde se cravam as máscaras incertas das coisas e um pensamento disperso ou incaptado em nossa visão distraída.

Um lirismo despistador dorme em humildes objetos que a nossa mão ou o nosso pé despreza. Por que só a fotografia os descobre aos nossos olhos tão cegos para os nove décimos do mundo? Recomeça o enigma. As piores explicações serão as que nos divertirão mais, como sempre. Vamos procurá-las nos caminhos sem fim do mundo, cheios de surpresas maravilhosas, de brinquedos que não nos cansaram nunca desde o primeiro circo em nossa memória, de flores estranhas e bichos incríveis, de dragões e anjos ${ }^{14}$.

14 CUNHA, Sylvio da. Os pássaros do retratista. Letras e Artes, Rio de Janeiro, n. 37, p. 10, 6 abr. 1947. De forma separada, porém contígua, lemos um fragmento, não assinado, com o título "Rimbaud explica o método de sua poética", que diz: "Na Alquimia do Verbo, Rimbaud dá-nos a ideia do seu método: a busca sistemática da alucinação, a procura de uma linguagem que permita traduzir os estados mais confusos da alma graças a uma evocação sensual simultânea de um complexo de tendências obscuras. Recriar a emoção no leitor, em lugar de descrevê-la". A nova linguagem poética será, então, para a antiga, o que a velha fórmula mágica é para a prescrição do médico. "Eu escrevia silêncios - dizia ele - notava o inexprimível, fixava as vertigens e envaidecia-me de inventar um verbo acessível um dia a todos os sentidos". Nietzsche, cujos textos foram introduzidos em Paris pela Mercure de France, a revista do pai, diz, num fragmento póstumo sobre a mulher grega, que a vontade de potência que, a rigor, não passa de vontade de chance, para se tornar arte, esvai-se em mundos, estrelas, corpos e átomos; mas, mesmo assim, revela-se necessária, não para os indivíduos, mas para a própria vontade. Em Condições, Alain Badiou argumenta que Rimbaud usa esse método (a interrupção) porque sabia estar condenado à impaciência e por isso 
Já na segunda colaboração, sem comprometer a ideia de que a arte é refúgio do comportamento mimético, Sylvio avança um argumento que, embora insinuado já por Murilo Mendes em crônicas para Vamos ler (1936), e elaborado quase simultaneamente (1948) por Macedonio Fernández, na sua sombrologia, logo acolhida por Lezama Lima na revista Orígenes, se reiteraria também na teoria estética de Adorno, quando este argumenta que a arte completa o conhecimento unívoco daquilo que dela se exclui; mas isso acaba afetando sua própria univocidade, que corre o risco de desmanchar-se, porque a magia, que a arte seculariza, recusa-se a desaparecer, enquanto a essência mágica, em plena secularização, degrada-se, como mera superstição ou resquício mitológico.

Antes de recordar a reação produzida pela descoberta da fotografia no mundo das artes e das letras, não se pode deixar de imaginar o que terá sido a resistência entre a média da humanidade, sempre pouco flexível, contra o extraordinário invento. Não seria inconsequente acreditar na força de semelhante resistência, capaz mesmo de deformar o critério dos homens de elite, como por exemplo de Baudelaire e de Daumier.

A fotografia não foi um achado do século $\mathrm{XV}$, embora nessa época os elementos de onde ela saiu já fossem conhecidos. Felizmente, porque então teríamos a lamentar mais algumas fogueiras e alguns mártires. Embora em 1839 a eletricidade, o caminho de ferro e os hieróglifos estivessem dominados pelo homem, isso não quer dizer que ele já se tivesse libertado de todos os terrores ancestrais. As superstições abundavam mais que agora e entre elas as que se relacionavam com a figura humana e sua representação. Ainda hoje quebrar espelho é azar. Isso vem da crença em que o reflexo, não só no espelho, como na água ou

pretendia fixar vertigens. Trata-se nele da impaciência de verdade, em e por uma verdade, que não é senão fixação. A paciência é dedução, fidelidade; já a impaciência é o que acaba na e com a poesia de Rimbaud. A amarga vitória de Uma temporada no inferno é, de fato, uma vitória em relação ao indecidível. Por isso Rimbaud acredita que la vie est ailleurs. Da Cunha não devia ignorar os escritos de um colaborador do Mercure, Jean Epstein, sobre Rimbaud, tal como o publicado no L'Esprit Nouveau (1922) ou outros, como "Grossissements" (1921) ou "Langue d'or" (1922), gerados pela fixação da vertigem, a mesma que alimenta Anémic Cinéma. Antonin Artaud, cujo Sorcellerie et cinéma (1927) devia ser igualmente conhecido pelo autor, também foi muito marcado pela teoria das vertigens para redefinir o teatro e não seria descabido que Sylvio da Cunha tivesse se baseado em alguns livros recentes sobre Rimbaud, como o ensaio de Benjamin Fondane (1933) ou o de René Étiemble (1936), onde o conceito de fixar as vertigens é discutido. Sem contar Vertigo de Hitchcock, as História(s) do cinema de Godard são um desenvolvimento desse conceito: vertigem da História, história da Vertigem. 
outra superfície brilhante, é alguma coisa externa ao homem, mas que se lhe assemelha "como um irmão", a própria sombra é em suma, a alma. Qualquer acidente ou perigo acontecido ao vulto refletido era como se fosse ao sujeito em carne e osso. E isso ocasionava hábeis cuidados. Cobrir espelhos quando morre gente ainda se usa. Hoje será tradição, mas não faz muito tempo era medo de que o espírito do defunto carregasse o reflexo de quem passasse pelo vidro metalizado ${ }^{15}$.

\section{A sombra, nos diz Sylvio da Cunha, é a primeira representação não só do corpo humano, como também da sua alma ${ }^{16}$. Há de relembrar, em crô- nica posterior, que Leonardo da Vinci definiu a beleza como uma "gradação da sombra" e, para provar o que dissera, pôs a sua Virgem dos Rochedos numa gruta sombria ${ }^{17}$. Seja como for, a sombra já é crença comum entre}

abr.1947.

15 CUNHA, Sylvio da. O medo da sombra. Rio de Janeiro, Letras e Artes, n. 38, p. 11, 13

16 Da Cunha constata a existência de uma grande força catalisadora nos esforços das primeiras pesquisas com as sombras e essa força era a irrupção da burguesia, provocando "uma procura numerosa de retratos accessíveis, afastadas que eram para o seu poder aquisitivo as telas a óleo. No fim do século XVIII tinham aparecido dois novos meios de fixar as linhas fisionômicas, a silhueta e o fisionotraço. A primeira aproveitava o contorno da sombra para execução de um desenho. O segundo era um mecanismo complicado que, à semelhança de um pantógrafo, transportava o perfil definido por meios mecânicos para uma chapa de metal, que depois iria imprimir a imagem, tal como uma placa comum de gravura. Sem dúvida que na descoberta da fotografia há circunstâncias pessoais dos seus realizadores que nada têm a ver com o que se passava no mundo de então; mas o desejo de ver o próprio retrato como num espelho fiel e dos entes queridos, mais que desejo, necessidade da multidão inumerável, era um estímulo poderoso para os que se preocupavam com o problema da fixação das imagens", tanto em pontos afastados da Europa, quanto no Brasil. Ver CUNHA, Sylvio da. A fotografia, arte burguesa. Letras e Artes, Rio de Janeiro, n. 43, p. 13, 1 jun. 1947.

17 Idem. Nadar. Letras e Artes, n. 41, p. 11, 11 maio 1947. Diz, ainda, nessa crônica: "Nadar é outro exemplo do elevado nível dos fotógrafos primitivos e da atração exercida pela nova arte na inteligência e sensibilidade dos homens do seu tempo. Gaspard-Felix Tournachon, que adotaria o pseudônimo de Nadar, nasceu em Paris em 1820. Sua existência testemunha um temperamento imaginativo e inquieto. Cursou a medicina, que abandonou antes de concluir os estudos. Em 1842 se iniciou na imprensa com artigos e desenhos. Deputado em 1844-46. Tomou parte na Revolução de 1848. Foi secretário de Lesseps, o construtor do canal de Panamá. Preso na Alemanha em 1848, durante alguns meses, acusado falsamente de espionagem. Voltou a Paris para ocupar-se de desenho, literatura, teatro e indústria. Fundou a Revue Comique em 1849, abrindo em seguida um atelier fotográfico para deixá-lo logo ao irmão, e disputá-lo depois, num rumoroso processo que terminou declarando-o inconfundível, o único Nadar. Sua atividade literária e teatral é intensa, colaborando em muitos periódicos e um deles é o Charivari. Não tarda, por outro lado, a apresentar o seu Pantheon-Nadar, onde focaliza todas as personalidades notáveis e a ser o primeiro a fazer a fotografia subterrânea (catacumbas de Paris) e a fotografia aérea. Seus retratos ficariam para sempre como obras-primas, em observação psicológica e em criação plástica. O seu atelier, que era ao mesmo tempo uma espécie de clube feérico ornado de flores e pássaros exóticos, de fontes decorativas, foi frequentado por Delacroix, Daumier, Corot, Millet, Baudelaire, Barbey D'Aurevilly, Theophile Gautier, 
os primitivos e também na cultura grega. No XI canto da Odisséia, acrescenta, Ulisses evoca os mortos que são chamados sombras, eidola. Sylvio da Cunha identifica assim a imagem, eidolon, com a representação, porque caberia esclarecer que, em grego, o conceito de eidolon se inscreve, com e contra o de eikon, na esfera da mimese, ao passo que phasma, phantasma ou phantasia pertenceriam à família de phaino, ou seja, da imaginação e do imaginário. Eidolon e eikon são gerados pela raiz wei-, mas só eidolon pertence ao domínio do visível, já que se formou a partir do tema weid-, que significa ver (e que sobrevive em latim: video), ao passo que eikon, assim como os verbos eisko ou eikazo, assimilar, e o adjetivo eikelos, semelhante, provêm de um tema weik-, que indica uma relação de adequação ou proporção. Em suma, o eidolon não passaria de ser a cópia de uma aparência sensível, ao passo que o eikon seria a transposição de uma essência. A maior superficialidade do eidolon e, em compensação, a irredutível densidade do eikon explicam que o primeiro tenha se reduzido a designar uma pura aparência, ou aos deuses que só existem através da sua imagem, enquanto o segundo tenha se aplicado às autênticas representações de Deus. Assim, em Bizâncio, opunham-se, irredutivelmente, os iconoclastas aos idólatras, o que mostra a avaliação positiva do ícone, em detrimento da negativa de ídolo. Como mostrou Jean-Pierre Vernant ${ }^{18}$, o eidolon homérico está ligado a três conceitos: o sonho, o simulacro e a alma dos mortos. Tanto o eidolon homérico quanto o posterior platônico associam-se a uma fumaça ou ao sopro do vento, isto é, a uma sombra (skia), e, portanto, não passariam de um

Saint-Beuve, Dumas, Berlioz, Wagner, Rossini e outros. Do próprio Nadar é a frase '- as mulheres são belas demais para serem fotografadas -', e, assim, só conhecemos dois retratos femininos de sua autoria, o de George Sand, já entrada em anos, e o de Sara Bernhardt. O maior mestre do retrato fotográfico jamais usou retoque. Buscava conservar a textura característica da face como força construtiva da imagem. Jamais fez posar um modelo, mas os deixava à vontade em suas atitudes naturais. Tendo acumulado uma fortuna, não tardou em perdê-la em suas experiências com aeróstatos. Suas aventuras foram espetaculares e tiveram em suspenso a população parisiense. Era um intrépido precursor da aviação, inspirou um romance a Jules Verne e ele mesmo escreveu um livro sobre as duas ascensões do Geant, em que quase pagou com a vida, com sua mulher e companheiros. Cabe-lhe a primazia de ter escrito a respeito de um direito do ar, e essa obra reunida a outras de sua atividade literária formam uma curiosa e original bibliografia. Faleceu em Paris, em 1910, com 90 anos e o seu arquivo, continuado pelo filho, é um tesouro único no mundo, compreendendo efígies de várias gerações de homens ilustres".

18 VERNANT, Jean-Pierre. Mito e pensamento entre os gregos: estudos de Psicologia Histórica: Trad. Haiganuch Sarian. São Paulo: DIFEL/EDUSP, 1973. Ver também KERENYI, Karl. Agalma, Eikon, Eidolon. In: VÁRIOS AUTORES. Demitizzazione e Immagine. Archivio di Filosofia, CEDAM, Padova, p. 161-171, 1962, e MONDZAIN, Marie-José. Imagem, icone, economia. As fontes bizantinas do imaginário contemporâneo. Trad. Vera Ribeiro. Rio de Janeiro: Contraponto, Museu de Arte do Rio, 2013. 
chamariz, um engano, uma miragem. Não sendo fruto de construção humana, coube tão somente aos deuses fabricá-los, por serem eles os autênticos fixadores de imagens (eidolopoios). Assimilados, portanto, ao não-ser, em Demócrito ou Epicuro, os eidola são meros simulacros e diríamos que as imagens, enquanto eidola, só podem representar, em suma, aquilo que se vê, o que, em última análise, mostra a ligação dos eidola com a mimesis e sua diferenciação com relação à imaginação. Mais um traço da imagem-eidolon seria que ela só retém do modelo aquilo que se oferece à vista, isto é, o phantasma. Em consequência, o eidolon não consegue fisgar a essência do que ele próprio mostra, daí que Homero diferenciasse o fantasma (eidolon) de Hércules, que Ulisses encontra no inferno, da própria pessoa do herói (autos), que se encontrava, com os imortais, no Olimpo, o que prova, além do mais, que o eidolon era sinônimo da psyché. Na República platônica, a justiça na polis é apenas um eidolon, um simulacro da verdadeira justiça, que concerne, no entanto, ao regramento da alma e, não raro, o conceito de eidolon surge, em Platão, toda vez que o filósofo quer destacar a degradação que supõe a passagem do inteligível ao sensível, ou de um a outro patamar de sensibilidade. No Teeteto, por exemplo, o pensamento que se manifesta graças à mediação sensível da voz não é senão um fantasma (eidolon) da ideia. Poderíamos dizer, assim, que a fotografia registra, mas não vê. Como conclui Suzanne Saïd:

L'idole fait du visible, qui est tout son être, une fin en soi. Elle arrête le regard qui s'abîme en elle et lui interdit d'aller plus loin. L'icône au contraire porte en elle son propre dépassement. Elle ne fait que convoquer le souvenir de Dieu et n'est jamais qu'un moyen de lui témoigner l'affection qu'on lui porte ${ }^{19}$.

Coerente com sua compreensão fenomenológica, Sylvio da Cunha avança, então, uma hipótese que leríamos muito depois em "A imagem imemorial" (1986) e em O que resta de Auschwitz (1998): o respeito pelo cadáver não é um patrimônio da ética, mas nos remete a um dos estágios mais arcaicos do direito, que se confunde, a rigor, com a magia, ou seja, que honra-se o corpo defunto para impedir que a alma do morto, ou antes,

19 SAÏD, Suzanne. « Deux noms de l'image en grec ancien: idole et icône ». In: Comptesrendus des Séances de l'Académie des Inscriptions et Belles-Lettres, 131e année, n. 2, p. 309-330, 1987. 
sua imagem ou fantasma, permaneça, sem função, no mundo dos viventes, como presença ameaçadora (tal como a larva dos romanos e o eidolon ou o phasma dos gregos ${ }^{20}$.

O caos é a grande sombra e o reino das sombras é a morte. Os fotógrafos de 1850 eram manipuladores de sombras, da família de Édipo e Cassandra. Na criança e no primitivo há um medo instintivo da sombra. Facilmente ela se torna um tabu de grande poder sugestivo. Frazer assinala numerosas manifestações de medo da fotografia entre os selvagens. Alguns não se deixavam ficar a sós com retratos que os missionários penduravam nas paredes, temerosos de que estes se animassem e os atacassem. Em várias regiões da Europa foi observada a crença de que não se deve fazer a própria efígie, sob pena de morrer. Nas ilhas de Salomão, todo o indivíduo que pisar na sombra do rei é punido de morte, e em outros pontos da Oceania, os indígenas não saem jamais de casa ao meio-dia, hora em que não tem sombra, fato que os aterroriza. No folclore comum ao norte da Europa, o Diabo não tem sombra, assim como tudo o que the pertence, e os habitantes do Inferno de Dante não projetam suas formas no chão. No relato de Goethe, repete-se a história do guerreiro Tutaikawa, do qual a força diminui e aumentava com o comprimento da sua sombra. Ele é finalmente assassinado ao meio-dia, quando era menor o seu vulto na terra ${ }^{21}$.

Ao estipular que, entre os românticos, a sombra é um motivo melancólico e trágico muito frequente, Sylvio da Cunha ilustra esse tópico, de início, com um fragmento de Alfred de Musset:

\author{
Partout où j'ai voulu dormir, \\ Partout où j'ai voulu mourir, \\ Partout où j'ai touché la terre,
}

20 AGAMBEN, Giorgio. Quel che resta di Auschwitz: L'archivio e il testimone (Homo sacer III). Turim: Bollati Boringhieri, 1998. p.73.

21 CUNHA, Sylvio da. O medo da sombra. Letras e Artes, n. 38, p. 11, 13 abr. 1947. Da Cunha grafa Tutaikawa para referir-se a Tutenchamun, a quem Goethe descreve como imagem viva de Amun ("Lebendiges Abbild des Amun") e que originalmente chamava-se Tutenchaton ("Lebendiges Abbild des Aton"), a imagem viva de Aton. Agradeço a indicação de Maria Aparecida Barbosa. Caberia ainda pensar se, em Tutenchaton, não poderíamos ver a instância do vazio do tempo e da imagem, já que o todo tem um eschaton, um fim de tudo, na escatologia. 
Sur ma route est venu s'asseoir

Un malheureux vêtu de noir,

Qui me resemblai comme un frère ${ }^{22}$.

A ideia conforma uma dupla sobrevivência, não apenas poética, mas também cinematográfica, porque essa mesma estrofe é citada explicitamente nas legendas de um filme precursor do expressionismo alemão, $O$ estudante de Praga (1913), como bem assinala Adalberto Müller ${ }^{23}$. Depois de Musset, Sylvio da Cunha cita um fragmento de « Le jeu », de Baudelaire:

Voilà le noir tableau qu'un rêve nocturne

Je vis se dérouler sous mon oeil clairvoyant;

Moi-même, dans un coins de l'antre, taciturne

Je me vis accoudé, froid, muet, enviant

Sylvio se detém, sintomaticamente, no mesmo fragmento que o filósofo das passagens. Com efeito, relembremos que, em sua análise de Baudelaire, Benjamin diz que, psicologicamente analisado, o jogador, mesmo que persiga o lucro, não atende ao desejo. Sua pulsão talvez se explique por avidez, talvez por decisão, mas, em todo o caso, a situação é ilustrativa daquilo que o próprio Benjamin chamava a perda de experiência, porque, a seu ver, "o jogo recusa as ordens da experiência". Daí que o jogador lance mão da aposta, que é um meio para dar aos acontecimentos o seu caráter de choque, ao arrancá-los de seus contextos de experiência. Até mesmo os acontecimentos políticos adquiriam assim, para a burguesia, a forma de simples lances numa mesa de jogo, dizia Benjamin. Há, contudo, também no jogo, uma ideia normalizadora, semelhante ao trabalho assalariado, nos diz o crítico, que consiste em querer começar sempre de novo. Por tal motivo, para Benjamin, o ponteiro que marca os segundos - la seconde-é, em

22 Trata-se de um fragmento de "A noite de dezembro", que foi publicada pela primeira vez na Revue des Deux Mondes (1 dez. 1835) e que, na versão de Pedro Lyra, torna-se "E sempre onde só quis dormir,/ E sempre onde só quis sumir,/ E sempre onde toquei o chão,/ Sempre sentou-se do meu lado,/ Vestindo negro, um desgraçado/ Tão semelhante como irmão".

23 MÜLLER, Adalberto. O estudante de Praga: o duplo, o espelho, o autor. In: HAMBURGER, Esther; SOUZA, Gustavo; MENDONÇA, Leandro; AMANCIO, Tunico (Eds.). Estudos de Cinema I. São Paulo: Annablume/FAPESP/Socine, 2008. p. 15-24. 


\title{
Baudelaire, um autêntico parceiro do jogador. E no texto citado por Sylvio da Cunha, justamente, o ponteiro é mais claramente substituído por Satã2 ${ }^{24}$ :
}

\author{
Voilà le noir tableau qu'en un rêve nocturne \\ Je vis se dérouler sous mon oeil clairvoyant. \\ Moi-même, dans un coin de l'antre taciturne, \\ Je me vis accoudé, froid, muet, enviant, \\ Enviant de ces gens la passion tenace.
}

24 Sylvio da Cunha usa também o ponteiro como elemento diferencial entre um estilo clássico e outro romântico de fotografia: "É quase impossível não reconhecermos logo à primeira vista um clássico da fotografia. Uma calma gravidade, uma austeridade inconfundível se destaca nos seus retratos. Nada de efeitos de luz, de posições estudadas, de atenuações da nitidez por qualquer processo. Há uma absoluta honestidade e um realismo quase ingênuo do modelo e do fotógrafo. Entre um e outro sente-se uma aliança de boa vontade para o mesmo propósito". O que é notável é que essa simplicidade penetrante, essa naturalidade tão forte, que nos faz também participar, a um século de distância, do momento vivido por estes dois personagens, foram obtidas à custa de muito esforço. Um longo minuto de imobilidade sob luz deslumbrante. Um leve movimento e tudo estará perdido. Nem todos venciam a minúscula batalha com o ponteiro do relógio. Podemos imaginar a emoção das nossas bisavós nessas ocasiões, raras e extraordinárias. A coisa não era para brincadeiras, e tanto, que assim se descreve um studio fotográfico da época: "O pianoforte, a caixinha de música, o trinado dos passarinhos; os elegantes reposteiros; os belos quadros; a custosa galeria de retratos; a peleja dos raios de sol através das janelas de cristal; a estatuária, as gravuras; tudo feito para impressionar o visitante com um palácio de ideal magnificência, para sossegar o espírito perturbado e acalmar a ansiosa espera, preparando-o para a obtenção de um bom retrato".

À austeridade dos clássicos, que concentravam toda a atenção sobre a face e quando muito as mãos do modelo, sucedeu a maior intimidade e familiaridade dos românticos da fotografia, ao mesmo tempo preocupados em atender às exigências da clientela, que, temerosa de um excessivo desnudamento das linhas fisionômicas diante de possíveis olhares implacáveis, foi se afastando mais da objetiva, até aparecer em toda a plenitude da indumentária, reveladora da sua condição social e às vezes mesmo da importância pessoal. O fundo, que os primeiros mestres mostravam "despidos como um muro de igreja", já nessa idade da câmera ostentam um imponente décor capaz de assegurar infalível impressão de plácida ordem e prosperidade. Geralmente são reposteiros imponentes, móveis torneados com aplicações de bronze, um livro que ateste a ilustração do personagem, vasos floridos ou com folhas e ramagens, pendentes, colunas de jeito grego ou uma espécie de pedestal de inexplicável utilidade ou beleza, às vezes usado para apoiar o cotovelo, colocar a cartola e a bengala, mas que geralmente fica boiando sem sentido na fotografia, bastante poético pela quantidade imensa de obsoleto que encerra. Não são, portanto, só essas figuras de costumes desaparecidos ou esses aspectos de um mundo ignorado, que pulam do imprevisível, como um milagre, em nossos olhos, capazes de nos impressionar com violência. O pior são essas visões ideais de criaturas da qual nunca saberemos nada e que desesperam a nossa imaginação pelo seu mistério. Assim, o período romântico da fotografia o é duplamente, para os que viveram o seu tempo, e ainda hoje, para nós, como sensação retrospectiva. O fotógrafo é quase sempre anônimo e é certo que era muito mais conduzido pela sua máquina do que esta por ele. O trabalho é mais da objetiva, que anota uma profusão, uma agudez de detalhes sobrenatural e conquistando assim o espaço, de forma tão avassaladora, faz parar no tempo alguns minutos depressa devorados pelos anos velozes; mas quando todas as grades, todas as gavetas, todos os armários, todos os livros estão fechados, quando pensamos que tudo está bem morto, bem esquecido, tem força para trazer à tona em nossa contemplação uma imagem tão pura e cristalina que julgamos vê-la respirando através apenas de alguns centímetros de ar e de poesia". CUNHA, Sylvio da. Clássicos e românticos da fotografia, O medo da sombra. Letras e Artes, n. 45, p. 6, 22 jun. 1947. 
Mesmo sem participar do jogo, preservado num canto, o poeta sente-se inebriado por ele porque assim acessa-se o tempo, que não é senão a trama que entretece as fantasmagorias do jogo, tal como Anatole France percebera em Jardin d'Epicure. Se, no entanto, acompanharmos o raciocínio de Bergson, diríamos que só a atualização da durée retiraria o homem da obsessão do tempo. Enquanto isso, ele vive dilacerado pela experiência do Unheimlich.

A sombra é o duplo, a dualidade do homem, e assume então as formas mais angustiosas em Maupassant, Dostoievski e R. L. Stevenson (Le Horla, O duplo e Dr. Jekyll and Mr. Hyde). Assim, a própria imagem do homem é algo estranho e capaz de desencadear dramas terríveis, e o medo de fazer o próprio retrato, sombra fiel e inconfundível de si mesmo, é uma manifestação generalizada com raízes no fundo comum das superstições da humanidade. E há uma gama e uma gradação de escrúpulos, desde os povos da antiguidade e dos selvagens atuais, até o nosso tempo, onde se confirmam nos países civilizados. Os atos de magia sobre a efígie pessoal ainda hoje se praticam e nisso se funda o temor de entregar o próprio retrato em mãos estranhas que possam sobre ele operar malefícios mortais. É, portanto, muito compreensível a desconfiança pública com que foi recebida a descoberta da fotografia. E perfeitamente explicáveis os qualificativos de sacrílega e infernal, com que a estigmatizou uma gazeta de $1839^{25}$.

Para tanto, Sylvio da Cunha concentra-se, especificamente, nas relações de Baudelaire com a fotografia.

No seu Salon de 1859, Baudelaire disse coisas cruéis contra a fotografia. Hoje que o tempo já desgastou as arestas da famosa polêmica entre a afirmação e a negação da arte em matéria fotográfica, às vezes revive o caso, mas apenas quando se trata de defender a fotografia ou a pintura de seus desvios de mau gosto. Depois de lamentar que a obsessão da verdade oprimisse e abafasse o gosto da beleza, sobretudo por exigências do público, que não é naturalmente artista, espontaneamente 
artista, mas talvez filósofo, moralista, engenheiro, amador de anedotas instrutivas, tudo o que quiser, mas que em matéria de arte não pode julgar sinteticamente, porém de maneira analítica e, em suma, parcial, Baudelaire constata que o credo da época em que escrevia era o exclusivismo da natureza, o tabu de que arte só pode ser a reprodução exata do reino natural. "Assim, a indústria que nos desse um resultado idêntico à natureza seria a arte absoluta". E prossegue: "Um deus vingador atendeu os votos dessa multidão. Daguerre foi o seu messias. E então ela se disse a si mesma: Pois que a fotografia nos dá todas as garantias desejáveis de exatidão, a arte é fotografia. A partir desse momento a sociedade imunda se atirou, como um só Narciso, para contemplar a sua trivial imagem sobre o metal. Uma loucura, um fanatismo extraordinário se apossou desses novos adoradores do sol".

Para elucidar esse aspecto da reação produzida no espírito de Baudelaire, é preciso considerar que a fotografia primitiva, caracterizada pela objetividade sem discernimento e uma reprodução apenas estatística dos objetos, proporcionou ela mesma tais argumentos. As placas de colódio, que então se usavam, repassadas por contato no papel, e as objetivas retilíneas davam às fotografias uma nitidez e uma exatidão de minúcias insuperável. O grande ângulo de vista e a pequena abertura das lentes contribuíam para produzir um atravancamento de planos da perspectiva, com uma abundância fastidiosa de objetos inúteis, entre os quais o olhar corria sem saber onde fixar-se. Eis a fotografia do tempo de Baudelaire. Nada mais antiestético. E o instrumento ainda por cima caíra na unha das mediocridades, irremediáveis. Sobretudo se comercializara demais. Foi a época do realismo fotográfico, e dela unicamente sobrevieram os retratos documentários de Nadar, que a despeito da sátira de Honoré Daumier, num desenho famoso, não pretendia elevar a fotografia às alturas da arte.

Havia também um aspecto imprevisível, que não tivera tempo de sentir o poeta das Flores do Mal, mas que se tornou palpável para Rimbaud, numa noite de ócio e fantasia, momento vivido e sentido depois por muitos, do misterioso encontro com a poesia dos velhos retratos abandonados: "É um vetusto armário esculpido: o carvalho sombrio, muito velho, tomou esse ar tão bom da gente antiga. Ele está aberto e derrama em sua sombra, como onda de um venerável vinho, os cheiros cativantes. Todo alheio: é um montão de velhas velharias, de linhos odorantes e amarelecidos, de trapos de mulheres e crianças, de rendas 
fanadas, de chales da vovó com desenhos aduncos. É lá que estão os medalhões, as mechas de cabelos loiros ou brancos, os retratos, as flores secas, num perfume que se mistura aos perfumes das frutas. Oh! armário de antanho, tu sabes muitas histórias! E parece que queres contar teus contos, e murmuras, quando se abrem lentamente tuas grandes portas negras!" Infelizmente a fotografia, das mãos honestas de Nièpce de Saint-Victor, Daguerre, Talbot e Octavius Hill, não tardou a atrair os manejadores vulgares da câmera, capazes das maiores abominações e que justificam sem sombra de dúvida a indignação de Baudelaire. Por isso ele se refere revoltado aos jocosos agrupamentos de personagens ataviados como açougueiros e lavandeiras de carnaval, crispados em caretas de circunstância, em reconstituições ignóbeis de cenas da história antiga. Outro motivo da sua náusea incurável foi a mania do estereoscópio, surgida alguns anos depois, a serviço das inclinações obscenas de alguns. É bem certo que esse segundo capítulo da história da fotografia é um desastre. E não precisava mais nada para incompatibilizá-la em definitivo com um homem refinadíssimo como Baudelaire ${ }^{26}$.

Em sua cartografia do estranhamento, o crítico tenta, contudo, equilibrar-se entre explicações autonomistas da arte e outras que, como os diagramas desconexos (abgeschnurte Dynamogramme) de Aby Warburg, explicam que as imagens perdem sua significação originária, mas nelas sobrevive, porém, algum tipo de espectro suspenso, uma sombra. Em favor da primeira tese, diz que

Desde Taine ao brilhantíssimo Max Dvorak têm sido atribuídos às obras de arte valores históricos, intelectuais e religiosos. Essa consideração da arte como nutrida de motivos extrínsecos conduzia a vê-la como um efeito de imitação e não como criadora c autônoma. A autonomia da arte, que é um axioma da crítica moderna, resulta de seu principio subjetivo e individual, do seu caráter de conteúdo humano de sentimento e de vida, em suma, da riqueza de sensibilidade do artista. O dom das musas se resolve assim numa fórmula da essência divina em que os termos são gênio-criação-arte. A origem da confusão 
entre a arte, que é fundamental, e a técnica, que é específica, deve buscar-se no positivismo científico do século XIX, que conduziu a pintura por um caminho de pura intelectualização, perseguindo desesperadamente o ideal de fixar a natureza numa forma e numa cor abstratas, mudando deste modo de criador para especulativo o sentido da atividade da imaginação ${ }^{27}$.

\section{Todavia, em favor da segunda, isto é,}

No extremo oposto a Max Dvorak, que via na história da cultura a história da arte, situa-se Henri Wölfflin, para quem a história da arte é a história dos símbolos da visão, expressada da seguinte forma: desenvolvimento do linear para o pictural, ou seja a mudança de conceito da linha como guia do olhar para a sua progressiva depreciação; desenvolvimento sobre a visão de superfície da visão de profundidade; desenvolvimento da forma fechada para a forma aberta; desenvolvimento da unidade sobre a multiplicidade, e, finalmente, desenvolvimento da clareza absoluta para a clareza relativa dos objetos. A história dos símbolos da visão, que reflete as variações do gosto, mostra-nos como podem ir longe os limites da plástica. Mesmo assim, a inquietude dos artistas transpõe com frequência essas fronteiras e padece de estranhas miragens ${ }^{28}$.

Diante do impasse, Sylvio se questiona, a seguir, acerca do que Charles Caffin já se perguntava em seu livro de 1901, Photography as a Fine Art: The Achievements and Possibilities of Photographic Art in America.

27

Visão. Letras e Artes, Rio de Janeiro, n. 46, p. 6, 29 jun. 1947.

28 Sylvio da Cunha relembra, nesse texto, tanto Jules Romains, autor de um tratado, A visão extrarretiniana ou o sentido paraóptico, onde menciona os indivíduos que veem de olhos tapados, que veem ocorrências a enormes distâncias ou que veem o passado e o futuro, ou seja, os videntes, os hipnotizados, os supranormais, quanto William Blake, "que escrevia poemas premonitórios e iluminados, que pintava sonhos e espectros", e que afirmou, em seus livros proféticos, que "na eternidade tudo é visão". E para ele, segundo o autor, a arte já consistia num dom de eternidade que Deus dá aos homens com antecipação: "O universo é uma imensa placa fotográfica e tudo exerce sobre tudo uma ação misteriosa. Nós não percebemos a irradiação de nossa face senão sobre o ponto preciso onde uma placa fotográfica fixa-o sensivelmente. Mas se a irradiação se faz sobre essa placa, é que ela se faz em toda parte, não sensível, mas igualmente verdadeira. Cada homem enche o universo da sua imagem e se essa imagem não é em toda parte visível é que a ciência não dispõe por todos os lados o aparelho fotográfico: a imagem está sempre presente, é a placa fotográfica que falta!”. 
Cumpre elucidar que toda obra de arte possui a sua técnica e na fotografia, embora ela pareça às vezes demasiado absorvente, a imaginação, o gosto, a cultura e acima de tudo o poder criador do autor podem muito bem ter o seu lugar. Lewis Mumford afirma que há um menor número de bons fotógrafos que de bons pintores. Os que fazem creative photography, fotografia criadora, são na realidade muito poucos. E essa é que é a verdadeira fotografia, digna do nome de arte. O resto é artesanato, técnica, ciência, indústria das mais importantes da era moderna. Criação naturalmente exclui imitação, repetição e "academia". Mas não se chega a dominar os elementos do mundo exterior, ao desembaraço das próprias faculdades, sem ter passado pelas pegadas e pelos traços dos nossos maiores e sem ter aprendido tudo o que eles souberam. E é só fazendo do ponto onde eles ficaram o nosso ponto de partida que alcançaremos a ser originais. Ignorar o que já se fez e assim mesmo pretender criar coisas novas é uma pobre estultice ${ }^{29}$.

\section{A conceituação do cinema seguia via paralela. Tendo se perdido o maravilhoso (ou como diria Benjamin, a experiência),}

o cinema, como todas as artes que podem estar tanto em boas como em péssimas mãos, depois da morte do maravilhoso tradicional, foi se revelando o desencadeador de um novo maravilhoso, do mais alto poder de sugestão, porque penetra na consciência pelo sentido mais complexo, o sentido da visão. Uma fotografia em estado de sonho, eis o cinema. E quando o retângulo animado nos tem bem presos ao seu hipnotismo, eis-nos diante de um desafio às leis do tempo e do espaço ${ }^{30}$.

A montagem, portanto, estava mediada pelo fascínio que a imagem aurática, como explicaria mais adiante Roland Barthes, ainda era capaz de suscitar no espectador:

O movimento é a vida, mas, na sucessão de seu ritmo, há sempre um ponto culminante de beleza, de trágico, de comicidade ou Quando a fotografia se torna uma arte. Letras e Artes, Rio de Janeiro, n. 47, p. 6, 
de um interesse qualquer que ele seja. Entre muitas imagens supérfluas colhe-se a essencial. Isso se torna bem claro na obra-prima que é Ivan o terrível de Eisenstein. Excetuando o envenenamento da Tzarina, uma maravilha de cinema puro, a cena com a pesada taça lavrada que cobre os enormes olhos assustados, passando logo ao quadro seguinte do grande catafalco, impressionante pelo modo brusco da transição, o filme todo é uma sucessão de fotografias belíssimas que temos vontade não de ver em cinema, mas num álbum em que elas estivessem sempre ao nosso alcance. Há uma superioridade da estática sobre a dinâmica fotográfica, na eletividade consciente ou inconsciente, irresistível, do nosso espírito. Explica-se o sentimento de Baudelaire odiando o movimento que desmancha a harmonia da linha. O cinema é uma aplicação da fotografia dirigida por outros caminhos, mais restrita, ilustrativa e descritiva ${ }^{31}$.

Muito embora não seja dominante em seu trabalho, Sylvio da Cunha empenha-se, no entanto, em traçar uma genealogia da imagem brasileira, relembrando, como o fizera Machado de Assis, em crônica de 1864, que as primeiras fotografias no país foram obtidas pelo padre Combes, o capelão da corveta francesa L'Orientale.

Hóspede do Hotel Pharoux o padre fora visto em estranhas atitudes que intrigaram a alguns observadores e ocasionaram até a que fosse chamado pelo Imperador. Utilizando a técnica do daguerreótipo, o sacerdote reproduzira o largo do Paço, a praça do mercado, o mosteiro de São Bento, e, a pedido de D. Pedro II, que se interessara enormemente pelo caso, o palácio de São Cristovam. É provável que depois das do padre Combes as mais antigas fotografias feitas entre nós tenham sido as de Henrique Klumb e Afonso Rouel, fugitivos do exército francês, chegados sem recursos ao Brasil, trazendo como única bagagem uma máquina fotográfica. Em 1847 desembarcou no Ceará o

31

Jean Manzon. Letras e Artes, Rio de Janeiro, n. 53, p. 6, 31 ago. 1947. Teria tido notícia o autor do ensaio de Jean-Pierre Chartier ("Ivan le terrible et le problème de la plastique cinématographique". La Revue du cinéma, Paris, n. 1, out. 1946), onde o então jovem estudante de filosofia, interessado pelo cinema, aproxima Ivã dos Nibelungos, distanciando-o de Potemkim? Ele destaca também a estilização da maquiagem, que lembra figuras bizantinas, observação que seria retomada por Barthes mais adiante para pensar o obtuso. Sacrificar a verossimilhança à expressão plástica, esse teria sido, segundo Chartier, o objetivo de Eisenstein. Sylvio da Cunha, ao destacar a superioridade da estática em relação à dinâmica fotográfica e não descartar o trabalho do inconsciente, é da mesma opinião. 
irlandês Frederick Walter, trazendo consigo uma aparelhagem de daguerreótipo e diversos instrumentos de mágico. Foi nessa ocasião que o adolescente Insley Pacheco, deslumbrado com as prestidigitações do irlandês, acabou aprendendo a fotografar, percorrendo todo o norte do país, com grande resultado financeiro, o que lhe permitiu viajar aos Estados Unidos onde pôde aperfeiçoar sua técnica. Abriu estúdio no Rio em 1854 o nosso Nadar brasileiro, que era também bom pintor, hábil temperamento artista, dotado de entusiasmo, ânimo empreendedor e ousado, que o levava a pesquisar os últimos progressos da fotografia, sempre na dianteira dos colegas da época, e a apurar as suas qualidades de observação e sentido artístico em fotografias que são sem dúvida as melhores desse período. Assim Insley Pacheco introduziu sucessivamente em nosso meio o ambrótipo, processo que sucedeu ao daguerreótipo, por ser mais barato, e que em vez da chapa de metal prateado usava vidro, embora ainda em imagem positiva; o calótipo, processo de Fox Talbot, que de um negativo-papel extraia cópias positivas. Durante muitos anos esteve Insley Pacheco na rua do Ouvidor, 102 e o seu atelier foi um famoso ponto de convergência da nossa sociedade e da própria Família Imperial. Embora ainda em estado potencial, pois em 1815 não existia a fotografia, não faltou também um fotógrafo na célebre expedição do Conde da Barca, da qual se originou a nossa Escola de Belas Artes e de que faziam parte os dois Taunay e Grandjean de Montigny. Esse era Marc Ferrez que iria mais tarde interessar-se por fotografia e cujo filho, do mesmo nome, a ela ia dedicar um apaixonado fervor.

Na exposição geral de Belas Artes de 1884, o catálogo acadêmico compreendia a Pintura, a Escultura, a Arquitetura e a Fotografia. Marc Ferrez Filho, que então ostentava o título de fotógrafo da Marinha Imperial, apresentava diversas fotografias de navios de guerra brasileiros. Ainda expunham Modesto Ribeiro, no processo de desvestimento a carvão, e José Ferreira Guimarães, com fotografias da Igreja de São Benedito e da Capela mortuária de Lorena ${ }^{32}$.

32 E ainda arrola os especialistas em daguerreótipos que estavam estabelecidos no Rio de Janeiro em 1857: "Diogo Luiz Cypriano, na rua dos Ourives 34; Gaspar Antonio da Silva Guimarães \& Cia., na rua da Alfândega, 62, $2^{\circ}$ andar; Henrique Klumb, fotógrafo da Academia Imperial de Belas Artes, na Ladeira do Castelo, 18. Seu anúncio no Almanaque Laemmert de 1857 acrescenta: - dá lições; Oficina de Kornis, na rua dos Ourives, 43. Esse Carlos Kornis era um exilado político, professor de Direito na Universidade de Pest, ganhando então a vida como fotógrafo; Joaquim Insley Pacheco, já citado, inicialmente na rua do Ouvidor, 33; Oficina de Jules Casimir, "por um novo sistema, das 8 da manhã até as 4 da tarde", 
Dominante, porém, é o esforço do autor por definir uma estética para essa linguagem e, assim como de Baudelaire retiramos uma linhagem de poesia pura que passa por Mallarmé e Valéry, Sylvio da Cunha apresenta-se identificado com a fotografia pura, que definia por meio de três atributos:

$1^{\circ}$. - Intensificação do sentimento de percepção, pelo enriquecimento em nitidez e detalhe;

$2^{\circ}$. - Aumento dos valores espaciais pelo claro-escuro e perspectiva;

$3^{\circ}$. - Aparecimento da quarta dimensão - tempo - por efeito de alguma das qualidades anteriores ou pela existência de um elemento determinante ${ }^{33}$.

Para ilustrar os dois primeiros, deveríamos resgatar o que o próprio autor nos diz a respeito de Edward Weston, líder dessa tendência. Para início de conversa, é bom não esquecer que, assim como Weston representara, na exposição universal de Paris, em 1937, uma linguagem norte-americana, a busca de Sylvio da Cunha orienta-se por sua vez no sentido modernista

segundo reza o anúncio do Almanaque de 1857, na rua do Ouvidor, 66, defronte do Jornal do Comercio; Lewis \& Chaise, na rua da Ajuda n 9 (ambrótipo); Ricaud, rua de S. José, 105; Seraphim Duarte dos Santos, rua dos Latoeiros $n^{\circ} 68$; e na mesma rua $n^{\circ} 36$, Beauvelot e Duprat.

Quais seriam os amadores desse tempo? José Ruqui na rua do Ouvidor, 23 anunciava "completo sortimento de tudo quanto é necessário para o daguerreótipo, como sejam, máquinas para tirar retratos, chapas de todos os tamanhos, passe-partouts, quadros, caixinhas, bromme, sal de ouro, caixa para preparações químicas, fornos para mercúrio, Rotten-Stone, tripoli e rouge para polir chapas. \&c.\&c.”. Ostentando o título de fotógrafos da Casa Imperial, encontramos nos anúncios de 1870 os seguintes nomes: Carneiro \& Gaspar, Gonçalves Dias, 60; Christiano Junior \& Pacheco, Quitanda, 45; G. Leuzinger, Ouvidor, 33-36 ("Premiado na Exposição de Paris de 1867”); Joaquim Insley Pacheco, já na rua do Ouvidor, 102; José de Mello Arquellos, rua da Carioca, 74; Maugeon \& Van Nyvel, Ourives, 40 sob.; Modesto Ribeiro, Ourives, 77; Poluceno Pereira da Silva Manuel, Gonçalves Dias 55; Stahl \& Wahusdraffe. Sem a condecoração imperial havia ainda: José Ferreira Guimarães, Ourives, 38, $2^{\circ}$; José dos Reis Carvalho, Ourives, 2; Marcos Ferrez \& Cia., rua de S. José, 96; Miguel de Novais, "Cavalleiro da Ordem de São Maurício e São Lazaro", Ourives, 65; e mais 15 outros num total de 28. A fotografia triunfava no Rio. No ano da república, maior ainda era o número de fotógrafos e entre eles notamos os sócios Pedro Satyro Souza da Silveira, fidalgo da Casa Real de Portugal, e Eugênio Francisco Magarinos Torres, fotógrafos da Casa Imperial”.___. Os primeiros fotógrafos no Brasil. Letras e Artes, Rio de Janeiro, n. 64, p. 4, 9 nov. 1947. Para uma exploração recente do tema, VÁRIOS AUTORES. The Itinerant Languages of Photography. New Haven/London: Yale University Press, 2013; BRIZUELA, Natália. Fotografia e Império: paisagens para um Brasil moderno. São Paulo: Companhia das Letras/Instituto Moreira Salles, 2012.

33 CUNHA, Sylvio da. A fotografia pura. Letras e Artes, Rio de Janeiro, nº 51, p. 6, 17 ago. 1947. 
de uma feição brasileira das imagens, obedecendo talvez ao esquema proposto pelo ancestral, Tristão da Cunha, para entender o dualismo da alma sul-americana: sentimento local e imaginação europeia ${ }^{34}$ :

O Grupo F: 64 é de origem recente - 1933 - mas sua influência se tem estendido rapidamente na região de Los Angeles, San Diego, Seattle e San Francisco. Esse grupo tem a base de seu programa na fotografia pura, repelindo tudo o que possa, num negativo, atingir de leve que seja, essa espécie de edifício químico sagrado construído pela luz na chapa sensível. Condena todos os processos intervencionistas que constituem propriamente o chamado pictorialismo inglês, de carvão, gema, bromóleo, transporte, tiragens em high key e low key, assim como a ótica de soft-focus, admitidos desde longa data da forma mais liberal pela Royal Photographic Society (Londres), a autoridade que até hoje sempre tem reinado sobre os estados orientais dos Estados Unidos. O grupo F: 64 constitui uma sociedade fortemente unida pelas ideias bases de seu programa. $\mathrm{Na}$ parte oeste dos Estados Unidos seus adeptos são numerosíssimos e seus mais destacados elementos são Edward Weston, Williard Van Dyke, Ansel Adams, Sonia Noskowiak, Imogen Cunningham, Herny Swift, John Paul Edwards, William Simpson, Peter Stackpole, Dorotéa Lange, etc. ${ }^{35}$

34 «Le sud-américain artiste, raffiné, tout aussi éloigné du snob qui se pique d'être parisien que du nationaliste qui ignore le monde, émigre souvent en Europe, ou plutôt, y retourne, selon le mot d'un autre de nos critiques. C'est qu'il se sent des affinités sans correspondance avec le milieu natal, auquel cependant il reste attaché. De là son âme contraditoire, son instabilité, l'opposition du sentiment, qui est national, à l'imagination, européenne ». CUNHA, Tristão da. "Lettres brésilennes" (Joaquim Nabuco, Minha formação). Mercure de France, Paris, v. 85, n. 309, p. 174, 1 maio 1910. Em "História de Olivinha" (de Histórias do bem e do $\mathrm{mal}$ ), ele mesmo se reconhece mudável, condenado a recolher o riso e a mágoa do mundo, para criar com eles outro mundo. Sobre o autor e sua atuação na revista, ver AMARAL, Glória Carneiro do. O Brasil na revista Mercure de France. In: NITRINI, Sandra (Ed.). Aquém e além mar. Relações culturais Brasil e França. São Paulo: Hucitec, 2000. p.148-163. SAMUROVIC-PAVLOVIC, Liliana. Les Lettres Hispano-Américaines au "Mercure de France" (1897-1917). Tese (Doutorado em Filologia) - Universidade de Belgrado, 1969. Os modernistas brasileiros, talvez pela sua proximidade com Graça Aranha, não foram hostis a Tristão da Cunha. Afonso Arinos o elogiou na revista Verde de Cataguazes e Álvaro Moreyra, em A cidade mulher, o descreve como um desafio aos ídolos da multidão, um poeta disfarçado de filósofo, de sabedoria amável, delicado e irônico.

35 CUNHA, Sylvio da. Edward Weston. Letras e Artes, Rio de Janeiro, n. 50, p. 6, 3 ago. 1947. (Grifos no original). 
Tais estratégias afiançariam o aparecimento do terceiro traço aí apontado, a quarta dimensão ${ }^{36}$, questão relevante não só para Alfred Jarry ${ }^{37}$, que publicou alguns textos nessa linha no Mercure de France, como também para os pintores cubistas teorizados por Apollinaire, e até mesmo para Van Doesburg, Kandinsky, Kupka ou Duchamp; poetas como André Breton, inspirado por um texto de Oscar Dominguez, A petrificação do tempo, ou mesmo César Vallejo, que a desqualifica em "Un hombre pasa con un pan al hombro"; fotógrafos como Max Weber que, em Camera Work (1910), já se colocavam o problema da fotografia e a quarta dimensão, ou ainda artistas como Salvador Dali que, por sua vez, julgava-se, em suas pesquisas sobre a quarta dimensão, apenas um epígono de Ramon Llul, cuja arte combinatória, inspirada pelos cabalistas judeus de Maiorca, alimentou as artes da memória de Borges e do OULIPO. Em função dessa variada origem literária, Sylvio avança, em suma, uma hipótese:

O sentimento da fuga do tempo, lugar-comum da vida moderna, reclama uma forma de expressão rápida e profunda, simples, mas imensamente eloquente. Na literatura essa tendência é uma força vitoriosa, que está pouco a pouco criando um novo estilo de escrever: “... je suis rentré dans un pays que je connais bien, rythmes discrets et parfaits, tambours voilés, battements couverts des coeurs immortels" 38 .

$\mathrm{Na}$ fotografia, o poder de expressão é instantâneo. A imagem surge logo, forte e vibrante, diante dos olhos. Além de imediato, é mágico esse poder. Mágico no sentido de algo que não está bem definido e para o qual se ensaiam mil explicações. $O$ fato é que a forma adquire sobre a nossa sensibilidade, pelo simples fato de ter sido fixada, um poder que ela mesma não tinha. Surge então o mistério, a magia: um objeto cuja vista deixa-nos completamente indiferentes, transposto para uma superfície plana e

36 HENDERSON, Linda Dalrymple. The Fourth Dimension and Non-Euclidean Geometry in Modern Art. 2. ed. revisada. Cambridge: MIT Press, 2013; The Image and Imagination of the Fourth Dimension in Twentieth- Century Art and Culture. Configurations, n. 17, p.131-160, 2009.

37 JARRY, Alfred. Commentaire pour servir à la construction pratique de la machine à explorer le temps. Mercure de France, v. X, n. 19, fev. 1899; Gestes et opinions du Docteur Faustroll, pataphysicien. Paris: Eugene Fasquelle, 1911.

38 Da Cunha não identifica a passagem, que pertence a Léon-Paul Fargue, cujos melhores textos, Epaisseurs, Vulturne, Haute Solitude, são uma máquina de destruição do tempo, tentando separar Fargue de seu duplo, Alfred Jarry, ambos por sua vez marcados pela mútua admiração pelo conde de Lautréamont. 
limitada, produz-nos uma emoção estética. Bernard Berenson propõe a seguinte explicação em termos matemáticos, falando de plástica, mas aplicável à fotografia: a percepção de uma coisa cifra-se por 1 ; se a intensidade da percepção de 1 passa a 2, dando-nos a impressão de que uma das nossas faculdades tornou-se o duplo da que conhecíamos, experimentamos o prazer de um redobramento da nossa atividade psíquica, capaz de ocasionar uma sensação de euforia.

Outro fator que aumenta a força expressiva na fotografia é a sua concentração. Em nenhuma outra representação ela se faz tão rápida e tão viva, alcança uma tão perfeita unidade. De um só golpe abre a cortina sobre o romance, a tragédia, até o poema, um mundo de lembranças, de sensações, de sonho. Como na música, a sensibilidade se multiplica em finas arborescências, a imaginação se perde em caminhos de surpresas, dentro de realidades geradoras de fantasia.

Quando na fotografia há um elemento capaz de sugerir a sua quarta dimensão - tempo como uma sombra longa de fim de tarde, como uma ave pousada num velho relógio de sol, ela atinge a plenitude de seu sentido. No momento transitório e cambiante, uma face da eternidade que é possível contemplar livremente. Seria, portanto, explicável porque nos comovem tanto essas fotografias amarelecidas, em que os personagens parecem estar sob um véu de tempo, numa melancólica névoa, que a poucos centímetros dos nossos olhos os coloca tão desoladoramente distantes. Como na pintura, o sentido plástico da fotografia é um refinamento tardio. Na pintura egípcia, linear, de significação metafísica, não há plástica. A plástica aparece verdadeiramente como uma consequência arquitetônica, na coluna e na estatuária, no alto Egito e na Grécia clássica. Depois a encontramos no ideal florentino da forma e do desenho dos volumes e da perspectiva aérea, que dá lugar adiante do XIV século à concepção veneziana da cor como criadora de massa, em Ticiano. Sob a influência dos temperamentos dos pintores, ou a plástica se resolve numa cor abstrata na decoração pura, como em Matisse, ou na sublimação da forma, na dissociação cubista.

Na história da fotografia até quase 1920, há a constante obstinação de um equívoco que quase sempre a desviou da sua legítima meta. Salvo alguns clássicos pós-daguerreanos e um Atget ou um Steichen, encontramos uma legião de fotógrafos que faziam fotografia com motivos de pintura e frequentemente de aquarela. Não escapavam as marinhas e os flamboyants. No 
desenho magro e mesquinho da fotografia virada pintura, ficava sempre esquecida a plástica, que é a base de uma fotografia no seu verdadeiro sentido. (Convém ter sempre sob reservas o alvo subjetivo da estatuária e do desenho, às vezes da pintura, quase sempre ridículo e obsceno em fotografia).

O progresso dos instrumentos e materiais deveria, portanto, depois dessa época facilitar a formação de uma elite de fotógrafos que logo mostrariam as imensas possibilidades da criação com a câmera. Por último, ainda há um motivo capaz de explicar a fascinação pelas imagens argênticas, como esse estado especial de reação contra a vida vertiginosa, traduzindo-se num esforço por conservar as imagens saborosas e fugitivas, numa necessidade de repousar nas formas calmas da beleza impassível baudelaireana a imaginação demasiado fustigada por um excesso tanto físico quanto moral e intelectual de tumulto ambiente. Em meio à confusão das máquinas desencadeadas da época seria assim ordem e calma a intimidade da fotografia ${ }^{39}$.

\section{É, portanto, absolutamente coerente com o enfoque nômade (ordem e calma nos remetem ao "Convite à viagem") que Sylvio da Cunha abordasse a questão da crise do objeto, que vinha obcecando os surrealistas havia mais de uma década.}

Embora o mais correto seja buscar a poesia na própria poesia, muitos poetas têm encontrado motivos de inspiração na ciência e mesmo na indústria. Poderíamos citar ao acaso Lucrécio, Catulle Mendès, Verhaeren e Walt Whitman. Esses dois últimos até descobriram o imenso poema que pode ser uma esmagadora locomotiva. Quando alguns velhos temas da literatura começam a dar mostras de cansaço, é natural que o espírito procure no céu e na terra, e mesmo além do céu e da terra, novas fontes de lirismo.

Esse desejo de descobrir outros roteiros para o olhar ou para a imaginação, de deixar para trás o que já foi demasiadamente visto ou sentido com apaixonado fervor, leva a sonhar com mundos desconhecidos, que enervam ignoradas formas de vida. Não me será difícil assim divagar com um mundo sem atmosfera, sem oxigênio, sem nuvens nem ventos, onde as estrelas brilhem

ago. 1947. 
perpetuamente, povoado de seres sem respiração, silenciosos, comunicando-se por meio de fosforescências sutis; eis aqui um planeta não menos surpreendente, inteiramente líquido, com festas submarinas e peixes civilizados; ou uma esfera de fogo onde personagens incombustíveis, salamandras de lenda se cruzam em chamas vertiginosas; ainda mais belo seria um astro gasoso, como a cauda de um cometa, onde os seus habitantes flutuassem, diáfanos espectros; mas o mais invejável seria um universo todo magnético, com criaturas superimponderáveis, feitas de radiações e ondas. Como não pensar que existam olhos mais sensíveis que os humanos, capazes de ultrapassar a nossa estreita gama perceptível de quatro a sete décimos de mícron, de onde fossem capazes de perceber a escala completa de vibrações do éter sideral, podendo ver outras cores que não vemos, num oceano de eflúvios sem relação com o mundo físico?

Esses sonhos sempre nos seduziram. E estamos numa época em que a ciência se tornou um romance. Eles nos fazem entrever a possibilidade de encontrarmos ainda alguma coisa nova no velho universo. De fato há uma crise do objeto, que se faz sentir sobretudo em pintura. Não só do objeto que é preciso transportar ou criar no retângulo cruel e indiferente a nossa angústia de renovação, mas também crise de relações de coordenação e de interpretação. A imaginação antiga terá criado imagens novas? O centauro, o dragão, a sereia, a esfinge são formados da reunião de órgãos de seres diferentes, mas vulgares. Eis como podemos compreender o desespero e a grandeza de Picasso, o grande espanhol, o mais espanhol de todos os espanhóis, o ser capaz da reação mais arrebatadora, revoltado contra a ordem [...] a temática de proporções dos entes e das realidades. Picasso é um moderno Anjo Rebelado da Pintura. Sentiu-se igual a Deus e foi precipitado no inferno da sua tortura infinita, do seu desespero de criar um novo cosmos impossível.

Em 1924, André Breton propôs a fabricação e o lançamento em circulação de objetos aparecidos em sonho. Segundo Breton, muitos objetos de uso corrente são de uma utilidade puramente convencional, havendo, portanto, vantagem em substituí-los por objetos surrealistas. Estes, verdadeiros desejos solidificados, deveriam, segundo Breton, desencadear e exaltar as potências inventivas. Desta forma passaria a atividade onírica para a realidade. Salvador Dalí, em 1931, sugeriu a criação de uma nova categoria de objetos de função simbólica, inteiramente despidos do seu sentido concreto. Surgiu a necessidade de fundar uma física da poesia, segundo Paul Eluard. De aspecto 
mágico para o profano, a exposição surrealista de 1936 em Paris fez uma tentativa que ainda não estamos em condições de apreciar e mesmo de definir, para apresentar objetos em novo sistema de conexões capazes de reagir contra o vulgar quotidiano. Ensaiava-se ultrapassar as limitações da existência manifesta de um objeto, desvendando o seu simbolismo oculto esquecido, deformado, destruído, ou mesmo ainda não descoberto. Um valor banal de convenção ocultava quase sempre um poderoso peso de representação, revelador do pitoresco ou da força emotiva. Para dar lugar à realidade escondida passava a segundo plano o dado imediato. $\mathrm{O}$ surrealismo doutrinou a revolução total do objeto, desviando-o dos seus fins usuais e mesmo conferindo-lhe um nome novo (Breton). A perturbação e a deformação devidas a acidentes exteriores podiam completar o sentido, assim como o encontro casual ou a irracionalidade do objeto. Podemos verificar imediatamente e da maneira mais simples que a experiência surrealista não é apenas um divertimento pueril ou maníaco, mas alguma coisa de muito séria e cheia de consequências, muitas das quais ainda não pressentidas. Tomando como exemplo certos objetos valorizados atualmente, que o faro dos amadores de antiguidades vai descobrir na poeira dos bazares, santos de madeira, velhos mapas ou caixinhas de música, constatamos que esses objetos correspondem perfeitamente ao sentido surrealista. O seu valor aparente é insignificante em relação ao seu valor simbólico ou sugestivo. A caixinha de música, então, é capaz de fazer explodir um considerável potencial poético. O tempo retrocede quando a contemplamos. Sabemos que sob o pó de quase um século ela esteve silenciosa e desprezada. As mãos que a amavam estão há muito tempo mortas. Como devia ser grande e belo o silêncio antigo que ela rompia, maravilhando as moças do mil e oitocentos! Então como seriam frescos aqueles sorrisos e sem nuvens aqueles olhares! Para os nossos ouvidos habituados às violentas sonoridades da vida atual, o trinado da caixa de música obsoleta é uma voz desconhecida de um mundo inatingível, que de súbito se torna palpável e inteligível ${ }^{40}$.

40 Mas se a crise do objeto atingiu de modo tão empolgante a pintura, criando problemas de complicada solução, Da Cunha achava que "a fotografia, dada a sua juventude, não parece encontrar-se ainda numa posição tão dramática", excetuando Weston, nos Estados Unidos, e o grupo de Le Rectangle, liderado desde 1937 por Emmanuel Sougez e integrado por Pierre Adam, Marcel Arthaud, Serge Boiron, Louis Caillaud, Yvonne Chevalier, André Garban, Pierre Jahan, Henri Lacheroy, Gaston Paris, Philippe Pottier, Jean Roubier e René Servant, fotógrafos, poetas e escritores que usavam a câmera sem que se pudesse falar, na opinião de Sylvio da Cunha, em crise do objeto fotográfico, pois "não deixam de mostrar 
Deleuze conclui a primeira versão de Proust e os signos (1964) com um texto intitulado "A imagem do pensamento", onde nos diz que as ideias se envolvem no signo para nos forçarem a pensar e se desenvolvem no sentido, para serem necessariamente pensadas. Marcam o acaso de um encontro e o caráter imperioso do pensamento, fortuito e inevitável, ao mesmo tempo. Quatro anos mais tarde, Deleuze utilizaria o mesmo conceito, a imagem do pensamento, no terceiro capítulo de Diferença e repetição. Nele define a imagem como a figura mediante a qual se universaliza a doxa, da qual, no entanto, se permanece refém. A alternativa consistiria em buscar uma gênese do ato de pensar no próprio pensamento e, contra uma imagem dogmática do pensamento, o proustiano Deleuze se empenha, daí em diante, em captar um pensamento sem imagem, partindo da premissa de que pensar é criar e criar não passa de gerar pensamento no pensamento, ou seja, uma imagem imanente ${ }^{41}$.

Georges Didi-Huberman tem destacado o trabalho de Aby Warburg como uma reação do historiador das fórmulas de sensibilidade a duas experiências marcantes, não só profissionais, mas também pessoais: a loucura e a guerra. Os caprichos da montagem e das próprias imagens, que segundo Sylvio da Cunha fazem explodir um considerável potencial poético, traçariam não só uma história documental do imaginário ocidental, mas funcionariam até como uma ferramenta para captar e avaliar a violência política nas imagens da história. Através das sombras e dos rostos, das sombras sem rosto ou mesmo dos rostos-sombra, detectamos, de início, em Sylvio da Cunha, um autorretrato do próprio artista, ou seja, uma análise das relações entre arte e sociedade, no Brasil no imediato pós-guerra, mas, ao mesmo tempo, capta-se, nesses textos, a aporia de um esforço em que o sujeito não acaba nunca de se conhecer por inteiro. Uma imagem do pensamento e um pensamento sem imagem. Didi-Huberman associaria esses caprichos do olhar, como ele os chamava, às arrière-ressemblances, apontadas por Mallarmé. Com efeito, em "Catolicismo", lemos:

com frequência as suas invenções e surpresas, que se desenvolvem ainda rigorosamente dentro da fotografia pura. Para isso contribui o realismo da fotografia, grande criador de força lírica, e a sua versatilidade, capaz de surpreender a vida nos refúgios mais secretos e nas situações mais fugazes". Crise do objeto e fotografia. Letras e Artes, Rio de Janeiro, n. 61, p. 8, 12 out. 1947. (Grifos no original). Sobre o particular, veja-se o ensaio de Rosalind Krauss sobre surrealismo e fotografia, em seu livro Lo fotográfico. Por una teoría de los desplazamientos (1990). Barcelona: Gustavo Gili, 2002.

41 Ver MARRATI, Paola. Gilles Deleuze. Cine y filosofia. Trad. E. Bernini. Buenos Aires: Nueva Visión, 2003. p. 87-106; RAJCHMAN, John. Deleuze: un mapa. Trad. E. Marengo. Buenos Aires: Nueva Visión, 2004. p. 37-51. 
Sans cela, une pensée d'éblouir le vitrage de coupole constatant élévation et transparence à ce que la rumeur dénomme édifice social, n'importerait de faire même un pas en avant; sauf, ainsi, pour entrer, tracer, inaugurer, non obstant une arrière-ressemblance avec des gravités du passé, assombries en la mémoire et qu'instaure la foule.

\section{Fernando Scheibe traduz:}

Sem um pensamento de ofuscar o vitral de cúpula constatando elevação e transparência nisso que o rumor denomina edifício social, importaria pouco algum passo adiante. Salvo, para entrar, inaugurar e saudar uma protossemelhança com gravidades do passado, ensombrecidas na memória ou que a massa instaura ${ }^{42}$.

A arrière-fable que Foucault veria em Verne é a proto- ou transemelhança prevista por Mallarmé, que retoma uma tradição de repertórios iconológicos que nos remonta a Cesare Ripa, aos estudos sobre melancolia de Robert Burton, aos Caprici de Giambattista Tiepolo, às imagens de Arcimboldo, Jacques Callot e, fundamentalmente, Goya ${ }^{43}$. O caminho das imagens bifurca-se nesse ponto: ora o vemos feito de sombras na memória, ora o avaliamos como um sinal premonitório daquilo que a massa, daí para a frente, instaura. Sylvio da Cunha, sem deixar de ser um sofisticado sintoma deste último fenômeno, foi refém da primeira opção.

42 MALLARMÉ, Stéphane. Divagações. Trad. F. Scheibe. Florianópolis: Editora da UFSC, 2010. p. 198. Não nos esqueçamos que, em 1898, Mallarmé, em resposta a uma indagação do Mercure de France sobre as fotografias nos romances, manifesta-se « je suis pour - aucune illustration, tout ce qu'évoque un livre devant se passer dans l'esprit du lecteur; mais, si vous remplacez la photographie, que n'allez-vous droit au cinématographe, dont le déroulement remplacera, images et texte, maint volume, avantageusement ». MALLARMÉ, Stéphane. Oeuvres Complètes. Ed. H. Mondor e J.Aubry. Paris: Gallimard, 1945. p. 878.

43 Os caprichos do olhar de Sylvio da Cunha, revelariam, como os de Goya, "su contenido moral no prescriptivo, más bien comparable con una interrogación antropológica sobre las enfermedades de la razón. Si los Caprichos [...] se ofrecen sobre todo como intensas dramaturgias del claroscuro, que halla en la técnica del aguatinta una potente herramienta, es ante todo porque Goya fue un hombre de las Luces comprometido con la inquieta gaya ciencia de las Sombras, o de los monstruos, de la razón. En efecto, en los Caprichos descubrimos de continuo una especie de articulación dialéctica donde filosofía de las Luces y Romanticismo del sueño se confrontan o se intercambian constantemente, anunciando en el hombre disonante analizado por Caroline Jacot-Grapa, una subjetividad tensiva y sombría con la que el Romanticismo no cesará ya de jugar". DIDI-HUBERMAN, Georges. Atlas ¿Cómo llevar el mundo a cuestas? Madrid: Museo Nacional Reina Sofia, 2010. p. 84-85. 
Dono de uma arte verbal rigorosa, $[. .$.$] transporta para o campo$ da imagem fotográfica essa exigência extrema de meios e fins, que já o distinguia na elaboração do verso. Confirma desse modo a advertência de Man Ray: Si ta main tremble trop, laisse lá ton appareil et prends um pinceau. Sylvio da Cunha (sua mão é firme) trabalha a placa sensível com a mesma inexorável segurança de que se serve para agenciar a sábia, posto que velada orquestração de seus metros poéticos. A igual distância do realismo e do lirismo, ele nos dá não poemas, nem quadros, nem abstrações, nem documentos polêmicos: fotografias.

Mas é inevitável que de cada procedimento técnico, exercido com amor e rigor, se desprenda uma poesia específica. Mais ainda no caso especial da fotografia, cujo vocabulário já participa da magia poética - a gelatina, a imagem latente, o pancromático - e cujas operações se assimilam naturalmente às da criação poética - a sensibilização pela luz, o banho revelador, o mistério da claridade implícita no opaco, da sombra representada pelo translúcido - ó Mallarmé!...

A esse coeficiente prévio de sugestão, Sylvio da Cunha acrescenta um sóbrio e poderoso sentido plástico da imagem (não privativo da pintura), imagem que ele não apenas capta, senão também seleciona e como que torna a criar, aproximando ou fundindo elementos que se ignoravam (tão múltiplas são as formas, ainda as mais singelas, da natureza, que cumpre a qualquer arte revelar-nos). Suas fotografias dão testemunho de um artista geral, sutilmente dotado, combinando imaginação e artesanato, e sabendo muito bem o que se pode tirar, em invenção, da câmara escura onde adormeceram os pássaros do retratista. E não só em invenção. Acredito que ele também fará sua esta outra palavra de Man Ray: la Photographie qui console. ${ }^{44}$

Recebido em: 25/03/2014. Aprovado em: 25/06/2014.

44 DRUMMOND DE ANDRADE, Carlos. O poeta e a fotografia. Correio da Manhã, Rio de Janeiro, 20 jul. 1947. Saiu também, com modificações, como o título, "O poeta fora do mercado", em $A$ Tribuna, Santos, 22 jun. 1947 e foi, finalmente, reproduzido em Passeios na ilha. Rio de Janeiro, Organização Simões, 1952. p. 204-205. Sobre a fotografia, Man Ray escreveu «La Photographie qui console» (com quatro desenhos dele) na revista de Gualtieri di San Lazzaro, XXe Siècle, Paris, v. I, n. 2, 1938, bem como «Sur le réalisme photographique» (Cahiers d'art, Paris, v. X, n. 5-6, 1935) e a plaquette La photographie n'est pas l'art (Pref. André Breton. Paris: G.L.M., 1937). 